\title{
Air Rage: A Policy Research Study
}

\author{
Michaela M. Schaaf \\ University of Nebraska at Omaha
}

\begin{abstract}
Disruptive passengers are a growing concern to preserve the safety of crew and passengers in the air. A policy research study from 1996 to 2000 reveals a range of air rage incidents and airline policies. The various definitions are presented, as well as the scope of the problem. The causal factors are critical in understanding the root of the problem and in eradicating air rage incidents. The application of the policy research methodology revealed a void in data collection and future research needs such as policy evaluation. Policy makers, collegiate aviation educators, and industry personnel will use these results to inform decision making. This article contributes to the academic literature of air rage as an emerging aviation safety concern.
\end{abstract}

\section{INTRODUCTION}

The problem of disruptive passengers aboard aircraft is not a new phenomenon. One case dates as far back as 1950 , when a drunken passenger assaulted the crew on a flight from Alaska (Sheffer, 2000). Recently, however, the problem is becoming a more serious one. "Bad tempers are on display everywhere. The media report incidents of road rage, airplane rage, biker rage, surfer rage, grocery store rage, [and] rage at youth sports activities. Leading social scientists say the nation is in the middle of an anger epidemic that, in its mildest forms, is unsettling and, at its worst, turns deadly" (Peterson, 2000, p. 1A). One flight attendant explained that at 30,000 feet in the air, one cannot simply call a cop or throw an unruly passenger out the door like in a bar. ". . . there is no beefy backup on an airplane, and most of us aren't up there for the physical challenge. Why should we be? We're flight attendants, not Steven Seagal wannabes" (Hester, 1999b, p. 2). According to the International Transport Workers' Federation (ITF), airlines are obligated to ensure the safety of their passengers and employees (International Transport Workers' Federation [ITF], 2000b). Meanwhile, safety authorities are obligated by law to protect passengers and "ensure the occupational safety of flying staff" (ITF, 2000b, p. 19). Therefore, airlines and regulatory authorities are searching for means to eradicate air rage.

Definitions of Air Rage

It is often said that in order to solve a problem, one must understand it and be able to define it. However, organizations use different definitions of air rage, and unruly and disruptive passengers. The Sussex Police in the United Kingdom (UK) define a disruptive passenger as "Any passenger who, on an aircraft, carries out any action or pursues a course of conduct which is unlawful according to United Kingdom criminal legislation or which may amount to an [offense] under the Air Navigation Order" (Sussex Police, 1998, p. 109). Another definition states, air rage "is disorderly conduct, of any sort, which [jeopardizes] the safe and orderly operation of the aircraft or the well being of any of the occupants and their property. It does not 
have to be immediately violent, but it does have to be disruptive, threatening, or an [offense]" (Lucas, 1999, p. 1). The first definition explicitly states the actions of the individual must be criminal to be classified as a disruptive passenger. This definition excludes many disruptive incidents on board aircraft that are classified as air rage under other definitions. Meanwhile, the latter definition is more inclusive of a range of disruptions such as verbal abuse and threats.

Other definitions are even more vague. Ron Wilson, a spokesman for the San Francisco Airport, defined air rage as simply "interfering with crew members in the performance of their duties" (ABCNews.com, 2000, p. 2). Whereas, the UK defines disruptive behavior in terms of the Tokyo Convention. "Acts which are [offenses] against criminal law, and acts which, whether or not they are [offenses], may or do [jeopardize] the safety of an aircraft or any passengers or property therein, or [jeopardize] good order and discipline on board" (Vivian, 2000, p. 12). This definition is based on the legal treaty that has been adopted by many countries. Yet, all countries did not adopt the same definition of air rage.

The ITF recognizes the unique circumstances of aviation when it comes to disruptive passengers. An airborne aircraft cruising at 31,000 feet does not lend itself to standard security measures. There is a lack of an escape route and a lack of reinforcements to resolve the situation. Understandably, the ITF gives special attention to acts that occur after the aircraft doors have been closed (ITF, 2000b). The ITF defines disruptive passenger behavior as, "Any [behavior] on board an aircraft which interferes with cabin crew in the conduct of their duties, disrupts the safe operation of an aircraft, or risks the safety of occupants on board an aircraft, excluding the premeditated acts of sabotage or terrorism" (ITF, 2000b, p. 5). The ITF deliberately excludes "premeditated acts of sabotage or terrorism, intended to harm an aircraft and its occupants" as appropriate definitions and legislation already exist to address such incidents (ITF, 2000b, p. 5).

The above definitions do not include acts or assaults that occur on the ground. While these incidents are serious, the laws of the jurisdiction in which they occur cover them. Airport police and other local and national law enforcement have access to respond to these incidents. This is not the case for trans-oceanic flights. However, ground incidents are important to document and report. The ITF states bad behavior on the ground may be a prelude "to disruption in the air, and must be firmly dealt with" (ITF, 2000b, p. 5).

Both the Federal Aviation Administration (FAA) and the Dutch carrier, KLM, use definitions of varying levels. The FAA's levels increase in terms of the seriousness of the incident. KLM's levels vary based on the type of intervention required to resolve the situation. As evidenced by this paper, a single, comprehensive definition of air rage is needed to determine and categorize air rage incidents that are comparable around the globe.

\section{Scope of the Problem}

"When pilots are stabbed to death and flight attendants are taken to the hospital in ambulances, the skies are out of control" (Hester, 1999a, p. 1). Disruptive passengers have caused flight delays, emergency landings, diversions, inconveniences to other traveling passengers, psychological traumas, and serious injuries to crew and other passengers (Drudis, 2000). A British Airways policy stated that most airlines are experiencing an increase in the frequency and severity of disruptive passengers at check-in, at the gate, in lounges, and on 
board the aircraft (Jack, 1997).

"Defective passenger [behavior] ranges from non-compliance with safety instructions ... to actions amounting to verbal harassment or physical assault directed at staff, passengers or the aircraft" (ITF, 2000d, p. 1). A broad range of documented air rage offenses committed aboard aircraft is included as Appendix A. This is not a comprehensive compilation; rather it illustrates the range of actions that can be categorized as air rage. Knowing the broad range of incidents assists management in developing training programs to prepare employees to diffuse such a variety of situations.

\section{$\underline{\text { Studies on Air Rage }}$}

Two air rage studies were conducted in 1999. NASA conducted a study on commercial air passenger behavior problems using 1998 data reported to the Aviation Safety Reporting System. One hundred and fifty-two reports of air rage incidents were reviewed. Perspectives included those of both the pilots and the cabin attendants. A second study was conducted by the ITF in 1999. The ITF is a UK-based organization representing "5 million members in 136 countries, including approximately 500,000 flight attendants" (Sparaco, 2000, p. 51). The ITF undertook a survey of affiliated unions concerning the disruptive passenger policies of their airlines. Replies represented 64 airlines in 32 countries (ITF, 2000b). The findings from these studies are further discussed below.

\section{Characteristics of Offenders and Flights}

There is not a typical unruly passenger, says Ellie Larsen of the Association of Flight Attendants. "There are no boundaries. They could be male or female. They can be young or old. They cut across every social and economic class" (ABCNews.com, 2000, p. 2). The offenders include business fliers, and premium- and coach-paying passengers (ITF, 2000b). While there is no typical air rage offender, statistics from April to October 1999 reveal that offenses were committed by males $75 \%$ of the time, while females were less likely to commit an air rage offense, being suspects in only $25 \%$ of the incidents (Vivian, 2000). Additionally, in $66 \%$ of the incidents, the offenders were 20 to 39 years of age (Vivian, 2000). While these statistics do not profile an offender, they do provide an idea as to the type of offender more likely to commit an offense.

As with offenders, there is no typical flight on which an incident will occur. Incidents occur on scheduled as well as charter operations; on short-, as well as long-haul flights; and on all aircraft types, both wide- and narrow-bodied (ITF, 2000b).

$\underline{\text { Statistics }}$

According to International Air Transport Association (IATA) figures from a survey, air rage incidents increased fivefold from 1,132 in 1994 to 5,416 in 1997 (James, 2000; ITF, 2000a; ITF, 2000f). In a separate study of incidents from April 1999 to February 2000, approximately 1,100 incidents were reported (Vivian, 2000). The NASA Aviation Safety Reporting System (ASRS), a confidential reporting database for airline crews, reported that unruly passenger incidents increased by approximately $800 \%$ (ITF, 2000f). In 1997 , 66 incidents were reported. In 1999, 534 incidents were reported. One in four incidents was serious enough to warrant intervention by the flight crew.

The FAA statistics indicate air rage incidents in the U.S. have recently decreased. Table 1 indicates the number of passengers cited by the FAA for assaulting, intimidating, or interfering with an airline crewmember. 
Table 1. Citations of air rage by the FAA (Hilkevitch \& Taylor, 2000)

\begin{tabular}{|l|l|}
\hline Year & Citations by FAA \\
\hline 1995 & 138 \\
\hline 1996 & 186 \\
\hline 1997 & 307 \\
\hline 1998 & 292 \\
\hline 1999 & 187 \\
\hline
\end{tabular}

"But industry experts say the FAA statistics don't tell the whole story. Officials of the Air Transport Association, which represents 26 domestic carriers, say there were about 4,000 [air rage] incidents last year - counting incidents that fall short of felony offenses" (Topousis, 2000, p. 2). Eighty-four U.S. carriers transported 614 million passengers in 1998, and United Airlines reported 635 incidents of disruptive behavior (Hester, 1999a). Meanwhile, the FAA recorded fewer than 300 incidents on all 84 carriers. Obviously the data collection methods are not accurate (Hester, 1999a). The difference is attributed to the records the FAA collects. "FAA records only those incidents that airlines choose to disclose, the actual number of assaults is seriously underreported" (Hester, 1999a, p. 2).

"Despite tabloid headlines documenting instances of 'air rage', aggressive [behavior] by passengers is thankfully incredibly rare" (Virgin Atlantic, 2000, p. 16). David Fuscus of the ATA explained the number of disruptive passengers is small when compared to the 640 million passengers that will board U.S. air carrier aircraft this year.

\section{STATEMENT OF THE PROBLEM}

\section{Air Rage as a Security Problem}

Airline and airport security have responded to the increase in air rage incidents. Their job is to secure the airport and flight environments. Therefore, aviation security must respond to the air rage threat. Captain Stephen Luckey of the Air Line Pilots Association stated in his testimony before Congress, "Passenger interference is the most pervasive security problem facing airlines" (Taylor, 1999, p. 8). In the UK, local police have assumed the lead role on committees to monitor interventions, while airport-based security officers in the U.S. have also assumed a coordination role (ITF, 2000b).

Importantly, the threat to the safety of the passengers and aircraft is a security concern, as is the case with terrorism. David Hyde, Safety and Security Director for British Airways, stated, "There can never be any excuse or justification for violence. When you are 35,000 [feet] in the air, violence threatens not only one person but hundreds of lives" (Sherwin, 1999, p. 2). Many are concerned that the increase in air rage incidents will lead to an accident. Sarah Finke, spokesman for a transport union, stated, "It's only a matter of time before a serious accident is caused by one of these instances" (Peterson, 2000, p. 2A). ITF Deputy Secretary General Stewart Howard also emphasized this point. "The issue must be taken seriously. . . . It is a miracle that no accident has occurred yet as a result of air rage" (Sparaco, 2000, p. 51).

The NASA air rage study revealed distractions among flight crews due to unruly passengers. "In $43 \%$ of the passenger-related incidents, flight crews experienced some level of distraction from flying duties. ... In more than half of these distraction incidents, a pilot deviation was the consequence. ... In $22 \%$ of the total study incidents, a flight crew member left the cockpit to assist flight attendants in dealing with an unruly passenger" (National Aeronautics and Space Administration [NASA], 2000, p. 1). Ten percent of the 
cases resulted in flight crew errors. It also creates a dangerous situation now that aircraft primarily operate with only two members comprising the flight crew. Should one of the members be injured in a scuffle with a passenger, the safety of all on board may be jeopardized. The safety component of the issue is not to be overlooked.

\section{The Causal Factors of Air Rage}

Air rage is not limited to one cause. A variety and combination of causes led to the outrageous examples of incidents labeled air rage. All studies agree that alcohol is the greatest contributing factor. In a study by Northwest Airlines, intoxication was the factor in $25 \%$ of incidents, seat assignments were $16 \%$, smoking problems were $10 \%$, carry-on luggage disputes were $9 \%$, employee behavior was $8 \%$, and food service was $5 \%$. 'Undetermined' and 'Other' made up 27\% (Taylor, 1999).

\section{Alcohol}

In NASA's study of passenger misconduct incidents, alcohol intoxication was directly involved in $43 \%$ of the incidents (NASA, 2000). However, problems with alcohol should not be allowed to escalate to such a level. In fact, most aviation safety regulations specify that intoxicated persons should not be allowed to board aircraft (ITF, 2000b). Gate agents and cabin crew are charged with denying boarding to persons that appear drunk. This is problematic because it can be difficult to assess a stranger's level of intoxication (Prew, 1997a).

"It is the responsibility of passengers not to be drunk on boarding or to get drunk on the aircraft" (Jack, 1997, p. 28). Yet, the ITF stresses that passengers are not discouraged from drinking, nor are they advised that it is illegal to get drunk before or after boarding the aircraft (ITF, 2000a).
The ITF wants staff at airport catering outlets to be educated on the importance of preventing excess drinking as passengers prepare to board flights (ITF, 2000b). The ITF would also like these outlets to have a system by which they can notify carriers in the event that a patron becomes intoxicated.

Excess drinking is a problem on aircraft as the effects of alcohol are increased at altitude. In aircraft, intoxication occurs at a lower level of consumption due to the effects of cabin air pressure on alcohol in the blood (ITF, 2000b). An adult passenger can show impairment at a Blood Alcohol Concentration of only $0.04 \%$ at altitude. Therefore, an intoxicated passenger can present definite safety risks on board an aircraft (Prew, 1997a). Where a single drink at the airport is the equivalent of at least two drinks at altitude, passengers that may be sober when boarding the aircraft may be drunk at 30,000 feet (Wise, 2000).

In an effort to combat the problem, some flight attendants want to restrict or cutback the amount of alcohol served. "We're not asking for a ban on alcohol. We're asking for a policy that's a little more realistic," said Dawn Bader, president of the Association of Flight Attendants' United Airlines Council (Valles, 2000, p. 2). But a British Airways spokesman said there were no plans to stop the free drinks and supply. "We have no intention of being a killjoy and punishing our well-behaved passengers" (BBC News, 1998b, p. 3).

\section{Smoking}

"Anecdotal evidence suggests that air rage is more common on long-haul flights when passengers have been cooped up in a tight space for hours on end" (BBC News, 1998b, p. 3). Some of these incidents are attributed to 'smoke-starved' passengers. Smoking restrictions onboard aircraft cause frustrated smokers. As expected, flight duration was a factor in incidents involving 
smoking. Longer flights were more prone to encounter a frustrated smoker that displayed disruptive behavior (Vivian, 2000). German airline pilots even urged their employers to offer nicotine to these smokers in an attempt to avert more incidents of air rage (Loviglio, 1998).

"Frustrated smokers accounted for more than half of the 266 incidents of disruptive passenger behavior recorded by British Airways in 1997" (James, 2000, p. 20). In 1998, British Airways extended its smoking ban to all flights. As smoking is a factor in a high proportion of incidents, the ITF wants smoking policies that are designed with the aim of avoiding disruptive behavior as a central function (ITF, 2000b).

\section{Carry-on Baggage}

Statistics indicate $8 \%$ of all airline baggage is lost or stolen, causing passengers to carry-on their baggage (Fairechild, 2000). Research suggests cabin baggage issues are implicated in $10 \%$ to $15 \%$ of disruptive passenger incidents, leading the ITF to call for a uniform regulatory limit on cabin baggage (ITF, 2000b). The ITF hopes this will reduce passenger confusion as to airline carry-on limits no matter which airline the passenger selects.

\section{Management}

Some say airline management is to blame for passengers becoming unruly (Fairechild, 2000). "While the airlines are only partly to blame for delays, they are solely responsible for how they handle delays and other factors affecting a passenger's right to safe, fast, polite service and on-time arrival, and for making baggage available within a reasonable time" (North, 1999, p. 87). In other words, disruptive behavior may be a reaction to poor service received from the airline. The ITF survey indicates that poor service, such as delays and overbookings of aircraft, is a great source of aggression against passenger handling staff (ITF, 2000b).

$\underline{\text { Stress }}$

Stress is a widely recognized contributing factor to the air rage epidemic. A clinical psychology researcher, Jonathon Bricker, stated air rage is a symptom of travel stress (James, 2000). U.S. Senator Harry Reid of Nevada recognized this stress. He introduced Passenger Fairness legislation in July of 2000 in response to the stress airline management causes passengers in order to save money and maximize profits (Reid, 2000). Passengers today do not need to be told the experience is taxing on the nerves.

". the modern airport experience is
often an unpleasant one. Passengers
endure a succession of difficulties:
inadequate parking; confusing
check-in procedures; long lines at the
check-in counter; more lines at
security checkpoints; shrinking
airplane seats; insufficient overhead
bin space; small in-flight meals if
any; and maddening numbers of
delays caused by a safe but woefully
insufficient Air Traffic Control
system" (Hester, 1999a, p. 2)

Sarah Prew (1997a) warns as the stress levels continue to build, the airlines and the entire industry must soothe the problem, not aggravate it.

\section{Expectations}

The expectations of passengers have changed as the price of commercial airline travel has become more affordable to many. New customers are flying that have no previous experience in air travel. The gap between expectations of passengers and their actual experience has increased (ITF, 2000b). There should be a correlation 
between the service an airline claims to offer and what it can in practice deliver. The United Airlines flight cancellations during the summer of 2000 are an example of a difference in expectations. When a gap does occur, unfortunately it is the employees providing customer service that must deal with the passenger dissatisfaction (ITF, 2000b).

Terry Riley, a psychologist and travel-security expert, said a surprising number of first-class passengers end up in rage incidents because they feel more entitled to special treatment in first-class (Topousis, 2000). Their expectations are not aligned with the service they receive. "An executive may not like a flight attendant telling him what they can and can't do," said Riley.

\section{Air Quality}

The use of recycled air in aircraft cabins is a source of complaints by passengers. Not only is the air of poor quality, but it also contributes to air rage. Dr. Vincent Mark, M.D., stated the "Curtailment of fresh air in airplanes can be causing deficient oxygen in the brain of passengers, and this often makes people act belligerent, even crazy . . . I'm positive about this, and it can be proven with a simple blood test" (Fairechild, 2000, p. 4).

\section{Passenger Traffic and Seating}

Another source of air rage is the amount of passenger traffic flying on airlines today. In 1999, the system load factor on U.S. commercial aircraft was $71 \%$. In July of 2000, traffic was at the recordsetting level of $80 \%$ ("World News Roundup," 2000). "With 50\% more passengers expected to be flying in the U.S. by 2010, an average day will feel like Wednesday before Thanksgiving" (North, 1999, p. 86). The passenger traffic obviously means more seats are filled on the aircraft and there is not enough personal space for travelers.

"Most people require a certain amount of personal space to feel comfortable. For at least five percent of the population, typical coach seats are too narrow and legroom is too restrictive to be comfortable" (Wise, 2000, p. 1). The ITF believes that seat pitch should be regulated to include minimum standards (ITF, 2000b).

$\underline{\text { Stereotype of Flight Attendants }}$

Finally, the stereotype of flight attendants is also a contributing factor. Some passengers have taken liberties with cabin crewmembers because the advertisements stated the passengers would receive personal, female attention (Taylor, 1999). But flight attendants must be promoted as safety professionals, for in an emergency situation, they must be treated with authority and respect (Taylor, 1999). "Unfortunately, the marketing of aviation very often explicitly undermines this staff role: crew and passenger handling staff are all too often portrayed as compliant service providers, willing and able to meet the individual requirements of passengers" (ITF, 2000b, p. 12).

\section{AIR RAGE POLICY:A METHODOLOGICAL FRAMEWORK}

\section{International Agreements and Awareness}

Several measures have been taken to combat the problem of air rage, from new legislation to penalties and airline actions. Oftentimes, air rage offenders are difficult to prosecute due to jurisdictional issues. Previously, under the Tokyo Convention, the state of aircraft registry was to assume jurisdiction for hijacking incidents (ITF, $2000 \mathrm{~b}$ ), although most governments felt that air rage, while serious, was not covered under this Convention. The U.S., UK, Australia, and Canada have changed laws in 
their respective countries to keep jurisdiction from preventing the prosecution of offenders. The four countries amended domestic laws to assume jurisdiction for air rage offenses as the act occurs onboard their registered aircraft and to include foreign inbound flights, provided the next landing is in one of the above four countries (ITF, 2000b; Prew, 1999).

During July of 2000, the ITF undertook a worldwide campaign to raise awareness of the air rage problem faced by flight attendants and other employees. In addition to educating passengers through leaflets at airports, the goal of the campaign was to encourage governments to pass laws increasing enforcement and prosecution of air rage offenses. Additionally, they encouraged governments to sign an international convention by the end of 2003 that would supercede domestic law and be effected in many countries at once. This international treaty would specify the jurisdictions for air rage offenses and close loopholes to ensure their prosecution (ITF, 2000a; Valles, 2000).

\section{Changing Penalty Policies}

Due to the jurisdiction problem associated with air rage, penalties for offenses, if any at all, vary depending on the country of prosecution. However, steps taken in the U.S. and UK demonstrate the seriousness with which the problem is treated by the authorities. In the spring of 2000, the U.S. Congress raised the maximum fine for passenger interference with crewmembers from $\$ 1,100$ to $\$ 25,000$ after U.S. unions lobbied for the increase. Meanwhile, the disruption of a flight carries a more staggering maximum of 20 years in prison and a $\$ 250,000$ fine (Valles, 2000). The issue of air rage is treated seriously in England. British Transport Minister, Lord Whitty, said, "Air rage is unacceptable and the [government] has decided to take strong action to ensure the safety of air crew and passengers alike. The safety of airline passengers must not be threatened by the [behavior] of selfish individuals" (Sherwin, 1999, p. 1). In September of 1999, new air rage penalties were established in response to the increase in air rage incidents. A new offense, acting in a disruptive manner, was added to the British Air Navigation Order in response to requests by the airlines. "The airlines argued that there was no measure to cover passengers not directly affecting the safety of an aircraft or causing criminal damage but to disrupting staff" (Sherwin, 1999, p. 1). Offenders are being sentenced to prison, even for first offenses, while comparable offenses committed on the ground would only dictate a suspended sentence or fine (Vivian, 2000).

\section{Airline Prevention Policies}

The ITF surveyed 64 airlines in 1999 and discovered only $32 \%$ provide air rage training to employees (ITF, 2000b). Some flight attendants criticized the airlines' efforts toward air rage training. One flight attendant said, "Airlines spend a lot of time teaching us how to deal with hijacking or bomb threats, but they do not teach us what to do if someone is violent or drunk" (Topousis, 2000, p. 4). The FAA, the ITF, and Virgin Atlantic believe the airlines' training efforts should be focused on prevention and keeping dangerous passengers off the aircraft (FAA, 1996; Virgin Atlantic, 2000; ITF, 2000b). Virgin Atlantic operates a training program named REACT. The program is based on the foundation that "prevention is better than cure" (Virgin Atlantic, 2000, p. 16). The program trains employees to diffuse situations before they escalate. Additionally, the ITF suggests other areas for staff training. These include: effective communication, de-escalation techniques, passenger restraint and control methods, 
role-playing, legal parameters within which staff can act, the scope for intervention across different scenarios, 'peace officer' skills, self defense, and management of crowd disturbances (ITF, 2000b).

In a heated air rage scenario, a tangible warning may be presented to an irate passenger in the form of a warning card. These are used increasingly by airlines to emphasize the seriousness of the incident, and to warn the passengers of potential legal action should the situation continue or escalate (ITF, 2000b). First used by British Airways (BA), "such warnings were quickly dubbed a 'yellow card' after the warning a soccer player gets when he is close to being ejected from the game. If handed a 'red card,' the BA passenger knows that he will be greeted by the cops rather than his family when the airplane lands" ("Unruly Passengers Challenge," 1999, p. 62). These straightforward messages in hard copy present the seriousness of the situation to the passenger. Appendix B includes the suggested content of a warning card by the FAA. Warnings, both verbal and written, have proved effective $41 \%$ of the time, being most effective in the presence of one's family (Vivian, 2000).

The captain can order the restraint of a disruptive passenger on the plane (British Airways, 1997). Therefore, the ITF states, "All aircraft absolutely must be equipped with restraint devices, such as handcuffs, restraint straps and restraint tape" (ITF, $2000 \mathrm{~b}$, p. 16). However, in their survey of 64 airlines, fewer than half, $42 \%$, actually provided restraint equipment. The ITF called this unacceptable and stated it represents a breach of the "carrier's duty of care" to customers and employees (ITF, 2000 b, p. 16). The crew must be able to fight back and subdue the unruly passenger. In some instances, they have improvised restraint devices. On one flight, several passengers had to provide their neckties to bind the wrists of one unruly passenger (Topousis, 2000). Another unruly passenger found himself bound to his seat by adhesive tape (Topousis, 2000). New technology in this area includes a body restraint package with which several airlines are experimenting. The device was designed by a former police officer and is thrown over the head and shoulders of the passenger to bind them to the seat (Topousis, 2000). Restraints may sound like a quick and easy fix to a situation of an unruly passenger. They are not. All other options should be exhausted before restraining a passenger. Trying to restrain an unruly passenger is a dangerous undertaking that exposes the crew to greater risk of injury (Prew, 1997b). Some airlines feel this potential danger to crew members is justification for not including restraint devices aboard their aircraft.

One punishment for the air rage offender is imposed by the airlines. This long-term punishment is banning air rage offenders from the airline in the future. Such a ban serves as a deterrent for business fliers that do not always have many air operators from which to choose. Such a ban not only affects their personal life, but their career as well. U.S. carriers, including Northwest, TWA, and United, have implemented policies that ban passengers for life. United Airlines even sends a severance letter from the company informing the banned flier that they are no longer welcome on United Airlines (Hester, 1999a). British airlines have taken an additional step in sharing the information and respecting the lists of fellow airlines. Virgin Atlantic joined Airtours in banning a man for life who attacked a flight attendant with a vodka bottle from traveling on any flight of Virgin Atlantic or Airtours (BBC News, 1998a). Richard Branson, the owner of Virgin Atlantic, and Gordon Bethune, CEO of Continental Airlines, want to 
compile a worldwide database of offenders that would prevent unruly passengers from being allowed on virtually any airline. "But just how an industry-wide blackballing system would work is unclear" as airlines do not share a common computerized database ("Unruly Passengers Challenge," 1999, p. 62). KLM is exploring a database of offenders that are banned. They must determine whether it is legal for them to record the information about passengers that display unruly behavior. "The internal use of such a list probably does not present a problem, but to build a watertight system KLM must be able to work worldwide with it, and it should also be accessible by third parties such as travel agents. This is more difficult to arrange. ... O Other criteria also need to be established, such as the point at which a passenger is placed on such a list, its security and how long data are retained" (KLM, p. 45).

In an article on unruly passengers, Sarah Prew identifies four areas of focus for the crew when dealing with an unruly passenger. First, deal with the incident as it happens; second, gather evidence; third, determine what the police need to know prior to the aircraft landing; and fourth, know the role of the aircrew on landing (Prew, 1999). Gathering evidence is one step that is commonly known to have failed the crew in a trial. It is important to gather as much evidence as soon as possible. Additionally, witness lists are important to make a case (Prew, 1999). Appendix C lists other tips in collecting evidence.

\section{Application of the Policy Research Method}

The application of policy research allows decision makers to improve policies or programs (Haas \& Springer, 1998). "More specifically, analysis for policy is called applied policy research" (Bowen \& Hansen, 2001, p. 164). Bowen and Hansen introduced the application of the policy research method to aviation applications (Bowen \& Hansen, 2000). The authors stated, "policy research occurs at a variety of points in the policy process and is situational in nature" (p. 164). They explained that policy analysis and research is "an appropriate tool in reviewing the outcomes of past policies in an effort to define future . . . policy options" (Bowen \& Hansen, 2000, p. 164).

According to Bowen (2001), "the policy research method is a study of evolving policy, utilizing both internal and secondary policy data." While the framework of policy research has been addressed in the scholarly literature as a process that relies on the application of research tools, it has not been operationalized as a tool itself. Bowen introduces the policy research construct to bridge the gap and provide policy researchers with a mechanism to operationalize policy research for the purpose of providing research-derived results. The results are derived from a systematic review, compilation, and synthesis of critical policy information.

Through application at a variety of points in the policy process, policy research was applied to examine the air rage phenomenon. The gap in academic literature on air rage provided an opportunity for a comprehensive policy research study into air rage. The air rage issues presented in this paper were explored through the application of policy research during the period 1996 through 2000. The study allowed the many facets of air rage to be analyzed over a period of time. A thorough review of the air rage epidemic in society reveals policy implementation of both governments and airlines. Analysis of the findings seeks commonalities, differences, and gaps for decision makers to review in the eradication of air rage. Finally, areas for future research in air rage 
were recorded as well.

\section{FINDING THE SOLUTION TO AIR RAGE}

Policy research reveals that different definitions of air rage do not resolve or address the issue of air rage; rather, they confuse it. Applying varying definitions of air rage in different jurisdictions leaves airlines wondering whether or not an incident will be classified as air rage. The jurisdiction in which the plane lands makes the determination of whether or not the incident will be classified as air rage based on the local definition. Vague definitions of air rage are also problematic for the same reason.

The scope of the air rage problem is disputed among airline management, national safety authorities, and cabin and flight crew unions. The exploration of air rage statistics and the range of offenses committed revealed contradictory data. The scope of the problem itself is one that is debatable. NASA and ITF follow-up studies may reveal the impact, if any, of policies implemented by airlines and governments to prevent future air rage incidents. A timeseries analysis or other study would provide useful data for policy evaluation.

In addition to the scope of the problem, the causal factors must be determined to prevent future incidents of air rage. Alcohol, smoking, carry-on baggage, management, and other causes were determined to be common factors influencing the air rage environment. The causal factors indicate the rage problems are not limited to aviation, but due to the unique nature of aircraft in flight, the factors must be diffused before one boards an aircraft, if at all possible.

Once the causal factors are known, the problems can be addressed. Measures taken by airlines, governments, and unions were reviewed to see what steps have been taken to combat air rage. Much ground has yet to be covered to prevent air rage offenses; however, policy evaluation studies can be undertaken to see if the measures implemented have influenced a rise or fall in the number of air rage incident reports. But in order to properly determine the scope of the problem, a comprehensive definition must exist so data are reported consistently and are comparable across airlines, organizations, and the globe.

\section{APPLICATION OF POLICY RESEARCH OUTCOMES}

The literature reveals the air rage problem is complex and requires more than one solution. First, passengers are voicing their discomfort regarding the 'sardine seating arrangements' of the airlines. This resulted in the startup of one airline in particular. JetBlue offers leather seats with more legroom, low fares, and new airplanes. CEO David Neelman said, "With our friendly service and hassle-free technology, we're going to bring humanity back to air travel" (Edmondson-Jones, 2000, p. 1).

Second, as passengers become increasingly agitated by delayed and canceled flights, complex ticket prices, and crowded airplanes; it becomes more likely that a Passenger Bill of Rights will be passed. Senators John McCain and Ron Wyden proposed an Airline Passenger Fairness Act that specified the rights of passengers when flights are delayed or canceled, including required compensation for passengers, disclosed sales information about flights, and other practices. This legislation was averted when the airlines voluntarily agreed to improve service. Since then, passenger complaints have risen (Reid, 2000; Bowen \& Headley, 2001). Senator Reid reintroduced such legislation in July of 2000 and January of 2001. Both pieces of 
legislation included provisions for passengers to exit aircraft that have been at the gate for more than one hour ("Right to Exit," 2000; Reid, 2001). Reid stated that such a provision would "help prevent 'air rage' incidents when passengers are forced to sit in parked planes for long periods of time" (Reid, 2001).

Third, the gap analysis of the literature reveals a void in the form of a comprehensive air rage database. Aside from an offender database, many are urging the development of a comprehensive air rage incident database. With airlines collecting different pieces of information, statistics are not comparable across airlines and countries. ICAO or IATA should establish a common reporting form with minimum required information to truly gauge the scope of the air rage problem. Data to be collected include associated issues with or causes of inflight violence; trends; factors, such as alcohol; type of incident, such as physical violence, unruly behavior, or verbal abuse; and locations involved; among others. In order for such a worldwide database to succeed, common reporting forms must be used to collect comparable data. Until such a program is implemented, the "understanding and eradication of sky rage will be hampered by inconclusive statistics and the arbitrary interpretations that result" (Hester, 1999a, p. 2). Qantas Airlines appointed a Security Analyst in 1996 to maintain and analyze a database of information on air rage within their airline and from other reports (Bee, 1996). Such a database could be a foundation from which to build.

\section{CLOSING THE FLIGHT PLAN: CONCLUDING OBSERVATIONS}

Through the application of the policy research methodological framework, it was revealed that different definitions of air rage are problematic, the scope of the problem is debatable, the causal factors must be addressed, and a void was uncovered in the collection of the air rage data. Policy changes are the likely solution. Due to the gaps revealed, immediate action is required to further close these gaps. Congress, the airlines, and the Department of Transportation must continue to act on behalf of the traveling passenger. The policies implemented to date are initial steps, reacting to the rise in air rage incidents in the 1990s. Collegiate aviation educators can incorporate this material in the curriculum through safety and security courses (Schaaf \& Bowen, 2001). Additionally, the faculty can conduct a share of the scholarly research that is desperately needed.

Never before have airplanes been so full, the system so congested, and the unruly passengers so out of hand. Future research in this area will be useful in determining correlations that may or may not exist among variables. Three passengers have been able to break through the cockpit door during violent air rage incidents. As the magnitude and seriousness of the incidents continues to grow, the preventative research must be advancing as well.

ITF Assistant General Secretary Stuart Howard said it is only a matter of time before a serious accident is caused by air rage and there is no reason not to act now to prevent future incidents (ITF, 2000c). 


\section{REFERENCES}

ABCNews.com. (2000, July 6). Keeping the skies friendly. ABCNews.com [On-line]. Available: http://more.abcnews.go.com/sections/us/dailynews/flightattend000706.html

BBC News. (1998a, November 1). UK: Air hostess hits back at bottle attacker. BBC

News [On-line]. Available: http://news.bbc.co.uk/hi/english/uk/newsid_204000/204906.stm

BBC News. (1998b, September 4). UK: When air passengers fly into a rage. BBC News

[On-line]. Available: http://news.bbc.co.uk/hi/english/uk/newsid_164000/164146.stm

Bee, G. (1996, September 11). Qantas Airways Limited Memo: Inflight violence. In International Air Transport Workers' Federation [ITF] (Ed.), Air Rage: The Prevention and Management of Disruptive Behaviour (pp. 53-59). London: ITF.

Bowen, B. D., \& Hansen, F. D. (2000, October). Implementing a national Small Aircraft Transportation System: A public infrastructure. Public Works Management and Policy, 5 (2), 160-169.

Bowen, B. D., \& Headley, D. E. (2001, July). The National Airline Quality Rating, results 2001. Paper presented at the Aviation Management Education and Research Conference, Montreal, Canada.

British Airways. (1997, September 17). British Airways policy: Disruptive and drunken passengers. In International Air Transport Workers' Federation [ITF] (Ed.), Air Rage: The Prevention and Management of Disruptive Behaviour (pp. 30-34). London: ITF.

Drudis, E. R. (2000, July 7). Airline workers fed up with rage. San Jose Mercury News [On-line]. Available: http://www.mercurycenter.com/premium/local/docs/airrage07a.htm

Edmondson-Jones, G. (2000, January 11). JetBlue Airways open for business. JetBlue Airways [On-line]. Available: http://www.jetblue.com/learnMore/pressDetail.asp?newsId=10

Employee attacked. (2000, July/August). Air Line Employee, 17.

Fairechild, D. (2000, July 12). Air rage. flyana.com [On-line]. Available: http://www.flyana.com/rage.html

Federal Aviation Administration. (1997, December). Notice of U.S. Federal Regulation Violation. In International Air Transport Workers' Federation [ITF] (Ed.), Air Rage: The Prevention and Management of Disruptive Behaviour (p. 68). London: ITF.

Haas, P. J., \& Springer, J. F. (1998). Applied policy research: Concepts and cases. New York: Garland.

Hester, E. N. (1999a, September 7). Flying in the age of rage. Salon.com [On-line].

Available: http://www.salon.com/travel/diary/hest/1999/09/07/rage/index.html

Hester, E. N. (1999b, August 17). The passenger from hell. Salon.com [On-line].

Available: http://www.salon.com/travel/diary/hest/1999/08/17/passenger/index.html

Hilkevitch, J., \& Taylor, T. S. (2000, July 7). Anger in the air: Crews seek to help restore peace. Chicago Tribune [On-line]. Available:

http://chicagotribune.com/news/printedition/article/0,2669,SAV-0007070287,FF.html

International Transport Workers' Federation. (2000a, July). Zeroing in on air rage [On-

line]. Available: http://www.itf.org.uk/SECTIONS/Ca/ti-article.pdf

International Transport Workers' Federation. (2000b, May). Air rage: The prevention and management of disruptive passenger behaviour. London: Author.

International Transport Workers' Federation. (2000c). Media information: ITF air rage good practice guide. International Transport Workers' Federation [On-line]. Available: 
http://www.itf.org.uk/SECTIONS/Ca/airrage/media12.htm

International Transport Workers' Federation. (2000d). Media information: What is air rage? International Transport Workers' Federation [On-line]. Available:

http://www.itf.org.uk/SECTIONS/Ca/airrage/media1.htm

International Transport Workers' Federation. (2000e). Media information: Some recent examples of air rage incidents. International Transport Workers' Federation [On-line]. Available: http://www.itf.org.uk/SECTIONS/Ca/airrage/media2.htm

International Transport Workers' Federation. (2000f). Media information: Air rage in figures. International Transport Workers' Federation [On-line]. Available:

http://www.itf.org.uk/SECTIONS/Ca/airrage/media3.htm

Jack, I. (1997, December 1). British Airways: Security advice circular 7/97. In International Air Transport Workers' Federation [ITF] (Ed.), Air Rage: The Prevention and Management of Disruptive Behaviour (p. 28). London: ITF.

James, L. (2000). Air rage or skyrage: Its psychology and solutions [On-line]. Available: http://aoloha.net/ dyc/airrage.html

KLM. Dealing with aggression: KLM's new policy. In International Air Transport Workers' Federation [ITF] (Ed.), Air Rage: The Prevention and Management of Disruptive Behaviour (pp. 35-52). London: ITF.

Loviglio, J. (1998, November 11). Air rage growing - Pilots say nicotine patch and less alcohol might help. Sightings [On-line]. Available: http://www.sightings.com/ufo/airrage.htm

Lucas, B. (1999, April/May). Disorderly passengers: The BALPA view. Journal of the British Air Line Pilots Association [On-line]. Available:

http://www.balpa.org.uk/the_log/Disorderly.html

National Aeronautics and Space Administration. (2000, April). Passenger misconduct: Effects on flight crews. Callback, 1.

North, D. M. (1999, October 25). Aviation Week's action plan for air travel. Aviation Week and Space Technology, 86-87.

Okada, B. (2000, July 6). Danger in the sky: 'Air rage' declines in U.S. despite surge elsewhere. Star-Telegram [On-line]. Available: http://www.startelegram.com/news/doc/1047/1:AOLNEWS3/1:AOLNEWS30706100.html

Peterson, K. S. (2000, July 18). Why everyone is so short-tempered. USA Today, pps. 1A-2A.

Prew, S. (1999, February). Unruly passengers: The role of the police. Aviation Security International, 24-27.

Prew, S. (1997a, December). Unruly passengers: The causal factors. Aviation Security International, 2 (4), 20-25.

Prew, S. (1997b, June). Unruly passengers. Aviation Security International, 2 (2), 4-9.

Reid, H. (2001, January 29). Reid introduces bills to improve airline travel in America [On-line]. Available: http://reid.senate.gov/ reid/press/01/01/2001129C43.html

Reid, H. (2000, July 19). Reid unveils Air Travelers Fair Treatment Act. News from United States Senator Harry Reid [On-line]. Available: http://www.senate.gov/ reid

Right to exit. (2000, July 24). Aviation Week and Space Technology, 47.

Schaaf, M., \& Bowen, B. (2001, April 19-20). Disaster preparedness, emergency response, and curriculum development: A white paper. Tim Forte Collegiate Aviation Safety Symposium. Denver, CO.

Sheffer, M. (2000). Changing attitudes toward in-flight violence and developing 
workable solutions. The Skyrage Foundation [On-line]. Available: http://www.skyrage.org

Sherwin, A. (1999, July 30). 'Air rage' curbs within weeks. The Times [On-line]. Available: http://www.sundaytimes.co.uk/news/pages/tim/99/07/30/timnwsnws01026.html?2443122UK

Sparaco, P. (2000, July 17). Flight attendants target zero air rage. Aviation Week and Space Technology, 51-52.

Sussex Police, Gatwick Division. (1998, May). A protocol for dealing with disruptive passengers and crime in the air. In International Air Transport Workers' Federation [ITF] (Ed.), Air Rage: The Prevention and Management of Disruptive Behaviour (pp. 106-111). London: ITF. Taylor, L. (1999, June). Stewardesses, stereotypes, and air rage. Aviation Security International, 4 (3), 6-9.

Topousis, T. (2000, June 19). Uncivil action. New York Post [On-line]. Available: http://www.nypost.com/06192000/news/31277.htm

Unruly smoker. (2000, July/August). Air Line Employee, 17.

Unruly passengers challenge airlines. (1999, October 25). Aviation Week and Space Technology, 60-62.

Valles, C. (2000, July 6). BC-air rage. ABCNews.com [On-line]. Available: http://abcnews.go.com/wire/Business/ap20000706_1357.html

Virgin Atlantic. (2000, June). Virgin reacts: Keeping the peace. Aviation Security International, 6 (3), 16-17.

Vivian, M. (2000, June). Disruptive passenger behavior: Analyzing the causes. Aviation Security International, 6 (3), 12-15.

Wise, L. M. (2000). Flight attendants: Then and now. Rosemarie Travel [On-line]. Available: http://sites.netscape.net/rosemarietravelr/airway2

Woman bites crewmember. (2000, July/August). Air Line Employee, 22.

World news roundup. (2000, July 10). Aviation Week and Space Technology, 24. 


\section{APPENDIX A}

\section{Select Air Rage Incidents That Illustrate the Range of Offenses}

1. A passenger took swings at the pilot (Okada, 2000).

2. A crew exceeded 250 knots below 10,000 feet due to a passenger that brandished a knife (NASA, 2000).

3. On final approach, a passenger removed his clothes in the lavatory and set fire to them in an attempt to set fire to the aircraft (NASA, 2000).

4. A passenger sexually assaulted a flight attendant as she tried to serve his meal. A senior company executive was prosecuted for then defecating on a food trolley. (Fairechild, 2000; Prew, 1997a).

5. A crew member needed 18 stitches after being hit with a vodka bottle (ITF, 2000).

6. A passenger grabbed the hair of a female clerk at check-in and banged her head on the counter repeatedly (ITF, 2000).

7. A passenger stormed the cockpit and assaulted a crew member when he was denied alcohol (ITF, 2000).

8. A passenger attacked the pilot and co-pilot intending to crash the plane and had to be subdued by crew members and passengers (ITF, 2000e).

9. A man broke an inside window of a British Airways 747 and crew and passengers had to overpower him (James, 2000).

10. A passenger was arrested after kicking the door on a flight from the United States (James, 2000).

11. "A violent passenger died on board a Hungarian airliner after cabin crew and passengers strapped him to his seat and injected him with tranquilizers. The passenger had been harassing people on board the flight from Bangkok to Budapest, punching the pilot and choking an attendant" (James, 2000, p. 7).

12. A Missouri carpenter broke into the cockpit of an Alaska Airlines flight, lunged for the controls and shouted, 'I'm going to kill you.' Passengers and crew members tackled the man and restrained him until the plane landed (ABCNews.com, July 6, 2000).

13. A female passenger entered the cockpit of an America West jetliner in flight and struck the co-pilot (ABCNews.com, July 6, 2000).

14. A passenger fought with her boyfriend, then threw a can of beer at a flight attendant and bit a pilot on the arm ("Woman Bites Crew," 2000).

15. A female passenger knifed a flight attendant in the neck because that crew member was trying to get the passenger's young daughter to put on her seatbelt for landing (Prew, 1997a).

16. Ian Brown, the former Stone Roses frontman, told a flight attendant he would chop off her hands and then banged on the flight deck door as the pilot landed the plane (BBC News, 1998a).

17. A plane diverted after an unruly passenger refused to stop smoking and became abusive to the flight attendants ("Unruly Smoker," 2000).

18. A woman was arrested after she attacked a Southwest Airlines employee. She "became upset when the employee cut up a credit card presented to buy a ticket. The employee had been alerted by the woman's bank that it was invalid, according to police. The woman lunged at the employee who was behind the counter and fell down. As [the 
attacker] stood up, she allegedly grabbed the scissors used to cut up her credit card and threatened the female employee with them" ("Employee Attacked," 2000, p. 17).

19. A Continental Airlines gate agent was slammed to the floor after telling a passenger to wait at the boarding gate. He "sustained three fractures to his cervical, neck and spine area, and may never walk again” (Hester, 1999a, p. 3).

20. Cathay Pacific banned two rock stars for life after they disrupted the flight with drunken and rowdy behavior (Wise, 2000). 


\section{APPENDIX B \\ Warning Card Content Suggested by the FAA}

Your behavior appears to be in violation of Federal law. If you fail to control your actions, federal authorities will be notified and requested to meet this flight.

THIS IS A WARNING THAT FEDERAL LAW PROHIBITS THE FOLLOWING:

Assaults, threats, intimidation or interference with a crewmember in performance of the crewmember's duties aboard an aircraft being operated. 14 CFR 91.11

Disruptive behavior due to alcohol consumption. 14 CFR 121.575

Alcohol-related disturbance created by a passenger

Consumption of an alcoholic beverage unless served by a crewmember

Alcohol service to a passenger who appears to be intoxicated

Failure to follow instructions given by a crewmember regarding compliance with passenger safety regulations such as the following: 14 CFR 121.317

No smoking in lavatories at any time

No smoking when 'NO SMOKING' signs are illuminated

Tampering with, disabling or destroying smoke detector installed in any airplane lavatory

Requirement to keep seat belt fastened while the 'FASTEN SEAT BELT' sign is lighted

Operation of an electronic device when prohibited

An incident report may be filed with the appropriate federal agency if you do not refrain from this behavior. The Federal Aviation Administration provides for fines of up to $\$ 10,000$. In the case of interference with a crewmember in the performance of crewmember duties, imprisonment for up to twenty years may be imposed in addition to the fine."

Source: FAA, 1997, p. 68 


\section{APPENDIX C \\ Tips on Collecting Air Rage Evidence}

There are certain pieces of information that will help the police prior to the aircraft landing. The information includes:

1. Where and when the incident took place.

2. The Incident Type. This is especially important if the offense is an obscure one. In any case, it helps the police to know what they are dealing with prior to meeting the aircraft.

3. How many people are involved in the incident and their gender.

4. The full names and ages of those involved in the incident. This allows the police to do a search on the person before the aircraft lands. It may be that they have a previous conviction that may affect the way the police decide to handle that person.

5. Where the aircraft is going to park at the airport. Although the ground staff determines this, if there is a particularly difficult or violent passenger on-board, for example, the police may decide to request that the aircraft be parked in a remote location.

Source: Prew, 1999 